\title{
Understanding Factors Affecting Livelihood Strategies of Firewood and Charcoal Producers in the Dry Lands of Ethiopia
}

\author{
Tensaye Abate \\ Ethiopian Environment and Forest Research Institute (EEFRI) \\ P.O.Box 24536 code 1000, Addis Ababa, Ethiopia
}

\begin{abstract}
This study identifies the determinants that influence the livelihood strategies of firewood and charcoal producers. The paper involves a survey questionnaire of 295 sample households based on snow ball sampling method in the dry lands of Oromia and Afar regions during 2019. The data were analyzed using descriptive statistics and multivariate probit (MVP) model. Results show that $39 \%$ of households derived their income from crop and $47 \%$ from wood fuel for those households whose livelihoods strategy in farming. Households in agro pastoral livelihood strategy about $58 \%$ and $21 \%$ derived their income from wood fuel and crop, respectively. Households whose depend their livelihood strategies on pastoral, $51 \%$ generate their income from wood fuel and $29 \%$ from wage. The model reveal that sex, age, education, family size, livestock holding, farm size, distance, off-farm activity, relief aid, training, market information, and membership on institution were significantly affected the livelihood strategy of firewood and charcoal producers in the dry lands of Ethiopia. Therefore, firewood and charcoal producer livelihoods are diverse and policy makers need to reflect on the most suitable ways of supporting sustainable use of dry land forest management and socio-economic intervention options.
\end{abstract}

Keywords: Charcoal, Dry land, Ethiopia, Firewood, Livelihood

DOI: $10.7176 / \mathrm{JETP} / 11-2-02$

Publication date: March $31^{\text {st }} 2021$

\section{Introduction}

Dry forests and woodlands are the dominant vegetation type in sub-Saharan Africa, covering over 17.3 million $\mathrm{km}^{2}$ in a total of 31 countries (Lawry et al., 2015; Chidumayo and Marunda, 2010). They are contributing to the livelihoods of millions of people globally. Dry forests and woodlands-derived incomes contribute considerably to rural and urban livelihoods and can reduce households' vulnerability by providing a source of savings, asset building, reducing poverty levels and improving wellbeing (Angelsen et al., 2014). Rural households typically pursue one of three major livelihood strategies in dry land areas: pastoralism, agro-pastoralism or sedentary agriculture (Niemeijer et al., 2005). Millions of inhabitants in developing countries derive their livelihood from farming, agro-pastoralism and pastoralism as the main source.

Human being's first source of energy is considered to be wood-fuel (Hosier, 1993). Charcoal and firewood are jointly referred to as wood fuel, and it is a major source of energy for most rural and urban households in developing countries including Ethiopia. They are the most globally used for energy supply. Wood is an important type of biomass and more than half is used for energy. According to Iiyama et al. (2014) charcoal is a sustainable energy source and can contribute substantially to reducing carbon emissions and greenhouse gases, if managed effectively. Moreover, its production and trade will become an important source of income for an estimated 12 million people by 2030 (Mwampamba et al., 2013). In Africa, 75\% of urban growth is expected to occur in small and medium-sized urban areas, with populations of less than 1 million (UN-Habitat, 2014). Literatures indicated involvement in charcoal and firewood trade can generate substantial incomes for participants (Minten et al., 2013; Schaafsma et al., 2012; Khundi et al., 2011).

In Ethiopia, firewood and charcoal production are used as their means of livelihood. Charcoal and firewood have the potential to provide reliable energy to millions of households in rural and urban people. Besides, charcoal and firewood supporting millions of rural and urban livelihoods through generation of income, financial flows from urban-rural and contributing to the overall national economy. The majority of Ethiopians use wood or charcoal for fuel, with natural forests being the primary source of supply for both products (Bekele, 2011). Despite the fact, the livelihoods strategies of firewood and charcoal producers in the dry lands of the country have not been determined. There are large research gaps in the charcoal and firewood literature, which has led to a lack of evidence-based decision-making (ICRAF, 2015). Understanding livelihoods strategy of target group of charcoal and firewood producers are very decisive to take cross cutting intervention to solve sophisticated problems and reducing poverty of rural households (Walelign, 2018). To design better intervention options and for better participation of both the direct and indirect wood fuel users in the management practices of woodlands, it is imperative to identify and understand the factors affecting the livelihoods strategies of charcoal and firewood producers. Hence, this study aimed to identify the livelihood strategies of charcoal and firewood producers and analyze the factor influencing their livelihood strategies. 


\section{Material and methods}

\subsection{Description of the study areas}

This study was undertaken in the dry lands of Afar region (Amibara and Awash Fentale districts) and Oromia region (Adami Tulu Jido kombolcha and Boset districts). One of the districts in the Afar region is Amibara district. Part of the administrative Zone 3, Amibara is bordered on the south by Awash Fentale, on the west by the Awash river, on the northwest by the administrative Zone 5, on the north by Gewane, on the east by Somali region, and on the southeast by Oromia region. In the district there are 18 kebeles (4 urban centers and 14 peasant associations). The Awash River passes through 14 PA's out of 18 peasant associations found in the district. The district extended astronomically between $9^{\prime} \mathrm{N}$ to $10^{\prime} \mathrm{N}$ latitude and $39^{\circ} 45^{\prime} \mathrm{E}$ to $40^{\circ} 30^{\prime} \mathrm{E}$ longitude. Awash Fentale district is one of the districts in the Afar region. Awash Fentale is bordered on the south by the Oromia region, on the west by the Amhara region, on the north by Dulecha and on the east by Amibara. The district extended astronomically between $9^{0} 14^{\prime} 60$ latitude and $40^{\circ} 00^{\prime}$ E longitudes.

Boset is one of the district in the East Shewa zone of Oromia region that lies between $8^{\circ} 24^{\prime}$ to $8^{\circ} 51^{\prime}$ ' $\mathrm{N}$ latitude and $39^{\circ} 16^{\prime}$ and $39^{\circ} 50^{\prime}$ E longitude. It is located about 125 Kilometers South East of the capital Addis Ababa. It is bounded by Fentale Woreda in the east, Awash River in the west, Arsi Zone in the south and Amhara region in the north. Adami Tulu Jido kombolcha distict is located in the heart of Central Rift Valley (CRV) in Oromia, southwest of Lake Ziway at altitude of 1500-2300 m.a.s.l. Ziway, one of the major towns in CRV, is the capital of this district. It is located at $150 \mathrm{~km}$ from the capital city of Addis Ababa. There are several seasonal and permanent rivers. Bulbula, the main river in the district, joins the upstream Lake Ziway and the terminal Lake Abiyata. The geographical map of the study areas was delineated using geographical information system (GIS) data as shown in Figure 1.

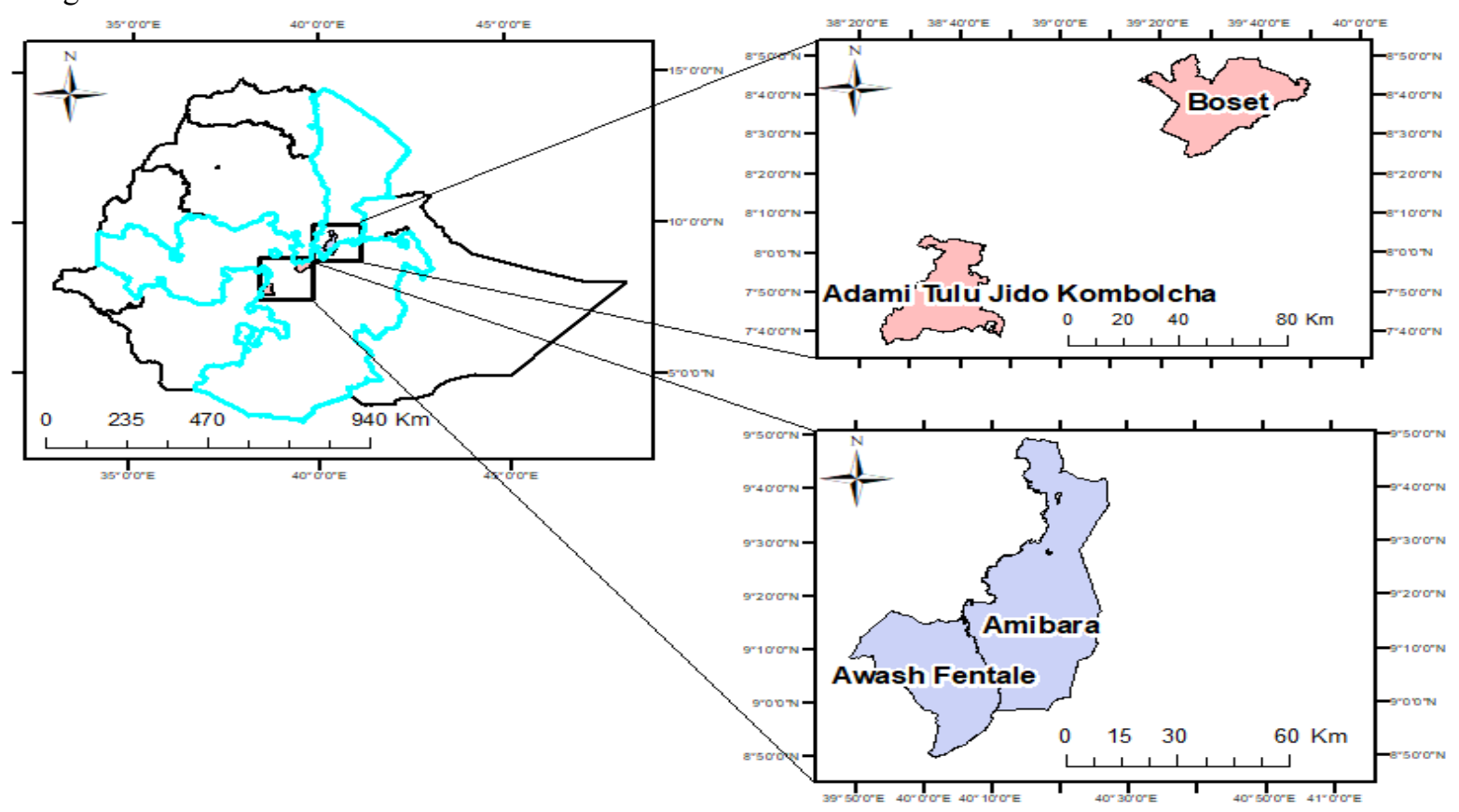

Figure 1 Map of the study areas

\subsection{Sampling and data collection}

A multistage sampling procedure was employed to select sample households from each sample districts. In the first stage, two region, namely Oromia and Afar regions were selected purposively based on the fuel wood and charcoal production potential with the consultation of regional environment protection bureau and bureau of agriculture and natural resource development. In the second stage, two districts in each region were purposively selected based on their livelihood style. Hence, Adami Tulu Jido kombolcha and Boset districts from Oromia region and Amibara and Awash Fentale districts from Afar region. In the third stage, 14 sample PAs were randomly selected with the consultation of district officials. In the last stage, a representative sample, 295 firewood and charcoal producers, were selected by snowball sampling method.

\subsection{Data analysis}

Using STATA 14 and SPSS version 20-software, the data was cleaned, coded, entered, sorted, and analyzed. Both descriptive and inferential statistics have been used to analyze the data. Frequency, percentage, mean, standard deviation, and cross-tabulation are included in the descriptive analysis. Continuous data were analyzed via one- 
way ANOVA in inferential statistical analyses. To identify the determinant factors that influence the livelihood strategies of firewood and charcoal producers, the multivariate probit (MVP) model were used. The descriptions of variables are described below in Table 1 .

\section{Model specification}

This study used a multivariate probit (MVP) econometric model, which simultaneously models the influence of the set of explanatory variables on each of the livelihood strategy, while allowing the unobserved and/or unmeasured factors (error terms) to be freely correlated (Lin et al., 2005; Belderbos et al., 2004). The model estimates from the multivariate specification improve over those from univariate specifications when the error correlations are significantly different from zero. In the MVP model estimated here, the choice of farming related to each of the livelihood strategy corresponds to a binary choice (yes/no) equation, and the choices are modeled jointly while accounting for the correlation among disturbances. The observed outcome of alternative livelihood strategies can be modeled following a random utility gained from each livelihood strategies formulation.

In MVP model, each subject has a covariate vector that can be any mixture of discrete and continuous variables. Each subject produces $\mathrm{J}$ distinct quintal responses or is classified with respect to $\mathrm{J}$ dichotomous categories. Specifically, let $\mathrm{y}_{\mathrm{i}}=\left(\mathrm{y}_{\mathrm{i} 1} \ldots, \mathrm{y}_{\mathrm{ij}}\right)^{\prime}$ denote the collection of observed dichotomous $(0 / 1)$ responses in $\mathrm{J}$ variables on the $\mathrm{i}^{\text {th }}$ subject, $\mathrm{i}=1, \ldots, \mathrm{n}, \mathrm{x}_{\mathrm{ij}}$ be $\mathrm{a} \mathrm{k}_{\mathrm{jx} 1}$ vector of covariates, $\mathrm{k}=\mathrm{k}_{1}+\cdots+\mathrm{k}_{\mathrm{J}}$, and $\mathrm{x}_{\mathrm{i}}$ can be a $\mathrm{J} \times \mathrm{k}$ matrix. For this particular study, the MVP regression model is described by a set of binary dependent variables. $\mathrm{Y}$ ij * as follows:

$$
\begin{aligned}
& Y_{i j}^{*}=X_{i j} \beta+\varepsilon_{i j}, j=1 \ldots m \\
& Y_{i j}=\left\{\begin{array}{l}
1 \text { if } Y i j *>0 \\
0 \text { otherwise }
\end{array}\right.
\end{aligned}
$$

where $Y_{i j}^{*}$ for $\mathrm{j}=1,2, \ldots, \mathrm{m}$ represents an unobserved latent variable of the livelihood strategy $\mathrm{j}$ applied by farmer $\mathrm{i}, \mathrm{X}$ is a matrix of independent variables reflecting household characteristics, $B$ is a vector parameter estimate and $\varepsilon_{\mathrm{ij}}$ is the error terms. Error terms have a standard normally distribution with mean vector zero and a covariance matrix with diagonal elements equal to 1 .

$$
\eta=\left[\begin{array}{ccc}
1 & \rho_{F A P} & \rho_{A P P} \\
\rho_{A P F} & 1 & \rho_{F P} \\
\rho_{P A P} & \rho_{P F} & 1
\end{array}\right]
$$

Table 1: Definition of variables included in the analysis

\begin{tabular}{|l|l|}
\hline \multicolumn{1}{|c|}{ Variable name } & \multicolumn{1}{c|}{ Description } \\
\hline Dependent variables & \\
\hline $\begin{array}{l}\text { LIVELIHOOD } \\
\text { STRATEGY }\end{array}$ & $\begin{array}{l}\text { If a household livelihood strategy farming }=1 \text {, otherwise }=0 \\
\text { If a household livelihood strategy agro-pastoral }=1, \text { otherwise }=0 \\
\text { If a household livelihood strategy pastoral }=1, \text { otherwise }=0\end{array}$ \\
\hline Explanatory variables & A continuous variable measured in years \\
\hline AGE & Sex of household head $(0=$ female and $1=$ male $)$ \\
\hline SEX & Education level of household heads in number of years \\
\hline EDUCATION & The number of families in the household \\
\hline FAMILY SIZE & Land holding size of the households in hectare \\
\hline LAND HOLDING & The total number of livestock in the household in tropical livestock unit \\
\hline LIVESTOCK (TLU) & Access to training or information on woodland forest management $(0=$ no, $1=$ yes $)$ \\
\hline TRAINING & Market information before you decided to sell firewood $\&$ charcoal $(0=$ no, $1=$ yes $)$ \\
\hline $\begin{array}{l}\text { MARKET } \\
\text { INFORMATION }\end{array}$ & Membership in formal and informal institutions of household $(0=$ no, $1=$ yes $)$ \\
\hline INSTITUTION & Households received relief aid $(0=$ no, $1=$ yes $)$ \\
\hline AID & Number of off-farm activities engaged $(0=$ no, $1=$ yes $)$ \\
\hline OFF-FARM & Distance to forest from their residences in kilometer \\
\hline DISTANCE & \\
\hline
\end{tabular}

\section{Results and discussion}

\subsection{Characteristics of sample households}

The descriptive statistics of the hypothesized variables of the study is presented in Table 2 . The mean age of agropastoral's likelihood strategies of households (42.3 years) is larger than the age of households whose livelihood strategy is farming (39.3 years) and pastoral (39.5 years). One ways ANOVA show that there is significant 
difference between the groups at $(\mathrm{p}<0.1)$. The mean family size of farming households $(6.5)$ is higher than agropastoral households (5.3) and pastoral households (5.6). Their mean difference is statistically significant between the groups at $(\mathrm{p}<0.01)$. The average livestock ownership for pastoral households $(9.3 \mathrm{TLU})$ is larger than for farming households (7.6 TLU) and agro-pastoral households (8.7 TLU) showing that their mean difference between them is not statistically significant at $(p<0.1)$. The average farm size of farming households $(2.4$ ha) is higher than that of agro-pastoral households (1.6 ha) and pastoral households ( 0.4 ha). The mean difference in the farm size between the groups is statistically significant at $(\mathrm{p}<0.01)$.The farm size includes cultivated, grazing, homestead, and woodlot land. Both farm size and livestock holding are the most important assets of households in the study districts. The mean years of education for farming households ( 4.9 years) are higher than households in agro-pastoral ( 0.6 years) and pastoral ( 0.4 years). The mean difference in the education level between the groups is statistically significant at $(\mathrm{p}<0.01)$.

With regards to sex composition, about $94 \%$ of farming, $92 \%$ agro-pastoral and $93 \%$ of pastoral households are male headed households. The one ways ANOVA indicate that there is no significant difference between the groups at $(\mathrm{p}<0.1) .50 \%$ of farming households, about $76 \%$ of agro-pastoral households and $27 \%$ of pastoral households can access market information. Their difference is statistically significant between the groups at $(p<0.01)$. Moreover, about $29 \%$ of farming, $63 \%$ of agro-pastoral and $98 \%$ of pastoral households are engaged in off-farm activities. Their difference is statistically significant at $(\mathrm{p}<0.01)$. About $99 \%$ of farming households, $85 \%$ of agro-pastoral households and $90 \%$ of pastoral households are access to training. Their difference is statistically significant between the groups at $(\mathrm{p}<0.01)$.

\subsection{Livelihood strategies and income composition}

Different livelihood strategy employed by different group of households accordingly their context of geographical location, resources endowment and market availability. Most commonly, economists group households by shares of income earned from different sectors of the rural economy. This study considered the income shares of each livelihood activity to conceptualize livelihood strategies. Accordingly, this study uses district assign criteria as bench mark to say farming, agro-pastoral and pastoral in the analysis of livelihood strategy determinants. Income portfolio analysis has been done for each household to measure the share of income from different livelihood options.

Table 2: Descriptive statistics of explanatory variables used in the analysis

\begin{tabular}{|c|c|c|c|c|}
\hline \multirow[b]{2}{*}{ Independent variable } & $\mathrm{F}(\mathrm{N}=80)$ & $\mathrm{AP}(\mathrm{N}=155)$ & $\mathrm{P}(\mathrm{N}=60)$ & \multirow[b]{2}{*}{ F-test } \\
\hline & Mean/SD & Mean/SD & Mean/SD & \\
\hline $\mathrm{AGE}$ & $39.28(11.73)$ & $42.31(11.77)$ & $39.48(10.16)$ & $0.089 *$ \\
\hline FAMILY SIZE & $6.49(2.93)$ & $5.29(2.28)$ & $5.63(2.46)$ & $6.024 * * *$ \\
\hline LIVESTOCK & $7.55(9.00)$ & $8.71(7.60)$ & $9.27(6.98)$ & 0.918 \\
\hline FARM SIZE & $2.41(1.18)$ & $1.58(1.11)$ & $0.36(0.49)$ & $46.894 * * *$ \\
\hline EDUCATION & $4.94(3.77)$ & $0.56(1.56)$ & $0.38(0.98)$ & $107.635 * * *$ \\
\hline DISTANCE & $0.96(0.61)$ & $5.44(4.62)$ & $23.9(11.36)$ & $270.046 * * *$ \\
\hline SEX (MALE) $\%$ & 93.8 & 91.6 & 93.3 & 0.207 \\
\hline MARKET INFORMATION (YES) \% & 50.0 & 75.5 & 26.7 & $26.892 * * *$ \\
\hline OFF-FARM ACTIVITY (YES )\% & 28.8 & 62.6 & 98.3 & $45.483 * * *$ \\
\hline AID (NO) $\%$ & 90.0 & 47.1 & 28.3 & $37.844 * * *$ \\
\hline TRAINING ACCESS (NO )\% & 98.8 & 85.2 & 90.0 & $5.478 * * *$ \\
\hline MEMBERSHIP INSTITUTION(NO) \% & 13.8 & 80.6 & 26.7 & $90.874 * * *$ \\
\hline
\end{tabular}

Source: Own calculation based on field survey; Note: $\mathrm{F}=$ farming, AP = agro pastoral, $\mathrm{P}=$ Pastoral

Where $* * * * *$ and $*$ refers to statistically significant at $1 \%, 5 \%$ and $10 \%$ respectively

From the income portfolio analysis, the percentage share of the farming households covers about $47 \%$ from wood fuel, 39\% from crop and 8\% from livestock. Whereas the broad livelihood activities for agro-pastoral households indicate that the share livelihood activities covers $58 \%$ from wood fuel, $21 \%$ from crop production and $15 \%$ from wage. Similarly, the percentage share of pastoral households indicates that the share of livelihood activities cover $52 \%$ from wood fuel, $29 \%$ from wage/salary and $8 \%$ from livestock. This result is consistent with the previous studies conducted by Mat et al. (2012); Saha and Bahal (2014); Kassie et al. (2017); Shiferaw et al. (2020).

\subsection{Factor affecting the livelihood strategy}

Table 4 presents the MVP model estimate of the factor affecting livelihood strategy by sample households. The maximum likelihood method of estimation was employed to estimate the parameter estimates of the MVP and statistically significant variables were identified. The Wald test for the hypothesis that all coefficients in each equation are jointly equal to zero is rejected suggesting that the variables included in the model explain significant 
portions of the variations in the dependent variables. The overall likelihood test ratio statistics indicated by the Chi-square statistics is highly significant, suggesting that strong explanatory power of the model.

Table 3: Income composition of sample households

\begin{tabular}{|c|c|c|c|c|}
\hline \multirow{2}{*}{ Income composition $(\%)$} & \multicolumn{3}{|c|}{ Livelihood strategy } & \multirow[b]{2}{*}{ F- value } \\
\hline & $\mathrm{F}(\mathrm{n}=80)$ & $\mathrm{AP}(\mathrm{n}=115)$ & $P(n=60)$ & \\
\hline Livestock & 8.13 & 3.16 & 8.36 & 0.617 \\
\hline Crop & 38.89 & 20.59 & 2.54 & $11.367 * * *$ \\
\hline On farm sub total & 47.01 & 23.75 & 10.90 & \\
\hline Food for work & 0.54 & 2.41 & 3.00 & $41.847 * * *$ \\
\hline Drought & 0.00 & 0.17 & 1.25 & $55.537 * * *$ \\
\hline Non-farm sub total & 0.54 & 2.58 & 4.25 & \\
\hline Firewood & 20.37 & 8.44 & 1.64 & $10.611 * * *$ \\
\hline Charcoal & 27.00 & 49.21 & 50.71 & $43.013 * * *$ \\
\hline Rent & 2.42 & 0.69 & 3.43 & $20.902 * * *$ \\
\hline Wage/salary & 2.65 & 15.33 & 29.07 & $168.002 * * *$ \\
\hline Off-farm sub total & 52.45 & 73.67 & 84.85 & \\
\hline
\end{tabular}

Source Own survey, $2011 \mathrm{~F}=$ Farming, AP = Agro pastoral, $\mathrm{P}=$ Pastoral

$* * *$, significant at $<1 \%$ probability level

Results of the study in Table 4 shows sex, age, education, livestock ownership, household size, farm size, distance to forest, off-farm activities, institution membership, market information, relief aid and access to training were significantly influencing the livelihoods of charcoal and firewood producers. Sex of the household head is negatively and significantly influences the livelihood strategy of farming households. Male headed households are engaged in more diverse livelihood activities than female householders. This may be due to male can control resources in rural areas, giving men greater access and opportunities to participate in income diversification (Owitti, 2015; Kassie et al., 2017). It was assume that male are more engaged in charcoal production and fuel wood collection than female due to physical nature of the activity. This result is in line with the previous studies conducted by Adugna (2005) and Berhanu (2007).

Age of household head is negatively associated and significantly influences the livelihood strategy of farming households. That accounts to the elderly farmers being well established, more experienced in agricultural production and more resistance to new ideas and information that hinder them from diversifying their livelihood strategies. Whereas, younger rural households cannot get enough farmland to support their families, and thus they get into diversified venture activities. This result is in line with studies conducted by Ambachew \& Ermiyas (2016); Seid (2016); Derbe (2020) stated that the younger are more likely to diversify their livelihood strategies into off and/ non- farm livelihood activities to support their livelihood. The number of livestock holdings is negatively influence the livelihood strategy of agro-pastoral and pastoral households. This means that the household with lower livestock holding would be obliged to diversify their livelihoods in order to meet the needs. The result is in line with the findings of Tesfaye (2003); Berhanu (2007).

Family size is positively associated and significant influence the livelihood strategy of farming and agro pastoral households. This implies family size increase, there is a potential of labor force to share working on charcoaling and fuel wood production and need of alternative income source. Large families are able to practice multiple activities whereas smaller ones tend to practice only agriculture with a livestock activity. This finding is similar to that of Bezemer and Lerman (2002). Likewise, education level of the household head is positively and significantly affects the livelihood strategy of farming and agro-pastoral households. Rural households' technical skill and knowledge may increase through education to absorb information on livelihood diversification. Skill and knowledge of households as well as good health and physical capability, which enable households to diversity their livelihood strategies to achieve sustainable livelihood (Serrat, 2017). Farm size is positively and significantly influences the livelihood strategy of farming and agro-pastoral households. This implies that a unit increment in farm size, the households are more likely to engage in farming for their livelihood. Hence, the households with a large farm size could able to cultivate a large area of plots and produce more (Kebede et al., 2014; Derbe, 2020) that enable the household to secure their livelihood.

Market information is positively and significantly influences the livelihood strategy of agro-pastoral households. With scarce or inadequate information sources and imperfect markets, social networks such as membership in rural institution facilitate the exchange of information and enable farmers to access information, training and credit. Training is positively and significantly affects the livelihood strategy of farming and agropastoral households. It helps in boosting the skill and knowledge of communities especially in remote and education inaccessible areas. Distance to forest is negatively associated and significantly influence the livelihood strategy of farming, agro-pastoral and pastoral households of firewood and charcoal producers. The possible reason for the result could be, households far from forest have no easy and quick physical access, to transport output and 
input from and to their residence and the chance of wage labor, are discouraging. This result analogy with the findings of Ambachew \& Ermiyas (2016); Asfaw et al., (2017) reported that the households at proximity to the road would like to choose livelihood diversifications strategies.

The numbers of off-farm activities engaged have a positive and significant influence on the livelihood strategy of farming households. Tsegaye et al. (2013) indicated wealthy households practice a number of non-farm incomegenerating activities, including firewood production, charcoal making, and petty trade. This finding concurs with that of Apata (2010) in that households with increased number of non/off-farm activities can make more money from non/off-farm sources. Relief aid is positively and significantly influences the livelihood strategy of farming household. It is a transfer of resources to rural households and/or individuals with the objective of enabling the community generate additional income and also build common asset thereby protect their asset depletion.

Table 4: A Multivariate Probit (MVP) analysis of factors affecting livelihood strategy

\begin{tabular}{|l|c|c|c|c|c|c|}
\hline \multirow{2}{*}{ VARIABLES } & \multicolumn{2}{|c|}{ FARMING } & \multicolumn{2}{c|}{ AGRO-PASTORAL } & \multicolumn{2}{c|}{ PASTORAL } \\
\cline { 2 - 7 } & Coef. & Std. Err. & Coef. & Std. Err. & Coef. & Std. Err. \\
\hline SEX & $-0.201^{*}$ & 0.1090 & 0.0175 & 0.3991 & 0.1564 & 0.2357 \\
\hline AGE & $-0.0918^{* *}$ & 0.0433 & 0.0159 & 0.0121 & -0.0295 & 0.0560 \\
\hline EDUCATION & $0.7221^{* * *}$ & 0.2475 & $0.2959^{* * *}$ & 0.0542 & 0.2987 & 0.8630 \\
\hline FAMILY_SIZE & $0.5101^{* *}$ & 0.2381 & $0.1486^{* * *}$ & 0.0551 & 0.1583 & 0.2119 \\
\hline LIVESTOCK & -0.0384 & 0.1284 & $-0.0417^{* *}$ & 0.0171 & $-0.2991 * *$ & 0.1469 \\
\hline FARM_SIZE & -0.0523 & 0.5586 & -0.1218 & 0.1039 & $-0.7383 *$ & 0.0177 \\
\hline MKT_INFO & -0.4589 & 0.0187 & $0.7446^{* * *}$ & 0.2541 & -0.7439 & 0.1047 \\
\hline TRAINING & $0.9504 *$ & 0.3142 & $0.9503 *$ & 0.4913 & 0.9236 & 0.2895 \\
\hline DIST_FOREST & $-0.5928^{* * *}$ & 0.0338 & $-0.0951^{* * *}$ & 0.0198 & $-0.5103 * * *$ & 0.1822 \\
\hline MEMBERSHIP & $0.0821^{* * *}$ & 0.0409 & $0.0236^{* * *}$ & 0.2533 & -0.5889 & 0.9779 \\
\hline OFF-FARM & $0.0904^{* * *}$ & 0.5088 & -0.1840 & 0.2544 & 0.3522 & 0.5812 \\
\hline RELIEF & $0.9387 *$ & 1.0620 & -0.0693 & 0.2520 & 0.0484 & 0.0062 \\
\hline CONS & 0.6527 & 1.7986 & 0.2267 & 0.6818 & 0.0224 & 0.7530 \\
\hline
\end{tabular}

Source: Own calculation based on field survey; Note: $\mathrm{F}=$ farming, AP = agro pastoral, $\mathrm{P}=$ Pastoral

Where $* * *, * *$ and $*$ refers to statistically significant at $1 \%, 5 \%$ and $10 \%$ respectively

\section{Conclusion and policy implication}

This study analyzed the determinants of the livelihood strategies of firewood and charcoal producer in dry land areas of Ethiopia. The livelihood strategies considered for this study are farming, agro-pastoral, and pastoral. Using MVP model the paper looked to analyze the factors that influence the livelihood strategies of firewood and charcoal producers. The results of the study indicated that most of the sample households diversified their likelihoods on farm, non-farm and off-farm livelihood activities. On-farm activities alone are not enough to sustain the livelihoods of farming household, agro-pastoral and pastoral households. Therefore, understand the livelihood strategy of firewood and charcoal producers is an important pathway towards environmental sustainability and social sustainability in dry land areas of Ethiopia. The study further shows that the livelihood strategies of firewood and charcoal producers significantly influenced by sex, age, education, livestock ownership, household size, farm size, distance to forest, off-farm activities, institution membership, market information, relief aid and access to training.

In conclusion, besides the on-farm livelihood activities, the non-farm and off-farm livelihood activities require paying attention to absorb the growing population and improving the living of smallholder farmers. Further, determinants of the livelihood diversification should be considered by responsible stakeholders. The results of the study point to the following implications. First, firewood and charcoal producer livelihoods strategies are diverse and need to reflect on the most suitable ways of supporting the livelihood in sustainable use of dry land forest management and socio-economic intervention options. Second, the roles of off-farm and non-farm activities are immense for the improvement and diversified the livelihoods of firewood and charcoal producers and thereby reduction of poverty and food insecurity.

\section{Reference}

Adugna, L. (2005). The Dynamics of Livelihood Diversification in Ethiopia Revisited: Evidence from Panel Data, Department of Economics University of Massachusetts, Boston.

Ambachew, M. D., \& Ermiyas, A. (2016). Determinants of Rural Household Livelihood Diversification Strategy in South Gondar Zone, Ethiopia. Journal of Agricultural Economics, Extension and Rural Development, 4(8), 548-560.

Angelsen, A., Jagger, P., Babigumira, R., Belcher, B., Hogarth, N., \& Bauch, S. (2014). Environmental income and rural livelihoods: a global-comparative analysis. World Development, 64, 12-28.

Apata, T.G. (2010). Linkages between crude oil exploration and agriculture development in Nigeria. Implication 
for relevant qualitative data collection and analysis to improve rural economy.

Asfaw, A., Simane, B., Hassen, A., \& Bantider, A. (2017). Determinants of non-farm livelihood diversification: evidence from rainfed-dependent smallholder farmers in northcentral Ethiopia (Woleka sub-basin). Development Studies Research, 4(1), 22-36.

Belderbos, R., Carree, M., Diederen, B., Lokshin, B., \& Veugelers, R. (2004). Heterogeneity in R\&D cooperation strategies. International journal of industrial organization, 22(8-9), 1237-1263.

Bekele, M. (2011). Forest plantations and woodlots in Ethiopia. Nairobi, Kenya: African Forest Forum.

Berhanu, E. (2007). Livelihood strategies of smallholder farmers and income poverty in draught prone areas: the case of Gena-Bosa woreda, SNNPRS. An M.Sc. thesis presented to the School of Graduate Studies of HarUmaya University.

Bezemer, D. \& Lerman, Z. (2002). Rural Livelihoods in Armenia: The Centre for Agricultural Economic Research, the Department of Agricultural Economics and Management Discussion Paper No. 4.03

Chidumayo, E., \& Marunda, C. (2010). Dry forests and woodlands in sub-Saharan Africa: Context and challenges. In Chidumayo EN and Gumbo DJ, eds. 2010. The Dry Forests and Woodlands of Africa: Managing for Products and Services. London, UK: Earthscan. 1-9.

Derbe, T. (2020). Determinants of Smallholder Farmers' Livelihood Strategies in Wogera District of Ethiopia. ERJSSH 7(1), 106-116.

Hosier, R. (1993). "Charcoal Production and Environmental Degradation: Environmental History, Selective Harvesting, and Post-Harvest Management." Energy Policy 21(5): 491-509.

ICRAF (2015). Developing sustainable tree-based bioenergy systems in sub-Saharan Africa., policy brief no. 28, 2015. Available from: http://www.worldagroforestry.org/downloads/Publications/PDFS/ PB15091. pdf.

Iiyama, M., Neufeldt, H., Dobie, P., Hagen, R., Njenga, M., \& Ndegwa, G. (2014). Opportunities and challenges of landscape approaches for sustainable charcoal production and use. In: Minang PA, van Noordwijk M, Freeman OE, Mbow C, de LeeuwJ, Catacutan D, editors. Climate-smart landscapes: multifunctionality in practice. Nairobi, Kenya: World Agroforestry Center (ICRAF).

Kassie, G., Kim, S., \& Fellizar Jr.,F. (2017). Determinant factors of livelihood diversification: evidence from Ethiopia. Cogent Social Sciences 3, 1369490.

Kebede, M., Haileselassie, A., Gebrehiwot, H., \& Luchia, T. (2014). Livelihood Diversification Strategies among Men and Women Rural Households: Evidence from two watersheds of Northern Ethiopia. Journal of Agricultural Economics and Development, 3(2), 17-25.

Khundi, F., Jagger, P., Shively, G., \& Sserunkuuma, D. (2011). Income, poverty and charcoal production in Uganda. Forest Policy Econ, 13(3): 199-205.

Lawry, S., McLain, R., \& Kassa, H. (2015). Strengthening the resiliency of dry land forest-based livelihoods in Ethiopia and South Sudan: A review of literature on the interaction between dry land forests, livelihoods and forest governance. Working Paper 182. Bogor, Indonesia: CIFOR.

Lin, C. T. J., Jensen, K. L., \& Yen, S. T. (2005). Awareness of foodborne pathogens among US consumers. Food Quality and Preference, 16(5), 401-412.

Mat, S.H., Jalil, A., \& Harun, M. (2012). Does non-farm income improve the poverty and income inequality among agricultural household in rural Kedah? Procedia Economics and Finance 1, 269-275.

Minten, B., Sander, K., \& Stifel, D. (2013). Forest management and economic rents: evidence from the charcoal trade in Madagascar. Energy Sustain Dev, 17(2), 106-15.

Mwampamba, T., Ghilardi, A., Sander, K., \& Chaix, K. (2013). Dispelling common misconceptions to improve attitudes and policy outlook on charcoal in developing countries. Energy Sustain Dev.,17(2): 75-85.

Niemeijer, D., Puigdefabregas, J., White, R., Lal, R., Winslow, M., Ziedler, J., Prince, S., Archer, E., \& McNab, D. (2005). Dryland systems. In Millennium Ecosystem Assessment, 2005. Ecosystems and Human Wellbeing: Synthesis. Washington, DC: Island Press.

Owitti, O.L. (2015). Gender differences and relations in rural household livelihoods of gog district, anywaa zone, gambella region, south-western Ethiopia. International Journal of Gender and Women's Studies 3 (1), 51-79.

Saha, B., \& Bahal, R. (2014). Livelihood diversification pattern among the farmers of West Bengal. Econ. Aff. 59 (3), 321-334.

Schaafsma, M., Morse-Jones, S., Posen, P., Swetnam, R., Balmford, A., \& Bateman, I. (2012). Towards transferable functions for extraction of non-timber forest products: a case study on charcoal production in Tanzania. Ecol Econ, 80: 48-62.

Seid, S. (2016). Determinants of Rural Households Livelihood Strategies : Evidence from Western Ethiopia. Journal of Economics and Sustainable Development, 7(15), 103-109.

Serrat, O. (2017). The Sustainable Livelihoods Approach. In Knowledge Solutions (pp. 21-26). https://doi.org/10.1007/978-981-10-0983-9_5

Shiferaw, W., Demissew, S., Bekele, T., \& Aynekulu, E. (2020). Relationship between Prosopis juliflora nvasion and livelihood diversification in the South Afar region, Northeast Ethiopia. 
Tesfaye, L. (2003). Diversity in livelihoods and farmers strategies in Hararghe highlands, Eastern Ethiopia, University of Pretoria, South Africa.

Tsegaye, D., Vedeld, P., \& Moe, S.R. (2013). Pastoralists and livelihoods: a case study from northern Afar, Ethiopia. J. Arid Environ. 91, 138-146.

UN-Habitat (2014). The state of African cities 2014. Re-imagining sustainable urban transitions. Nairobi, Kenya: United Nations Human Settlements Programme.

Walelign, S. Z. (2018). Quantification of rural livelihood dynamics. (September 2016). https://doi.org/10.13140/RG.2.2.27725.74723 